\title{
Synthesis, Characterization and Antimicrobial activity of Protected Dipeptides and their Deprotected Analogs
}

\author{
JATINDER PAL KAUR GILL ${ }^{1}$, SIMRANJEET SINGH ${ }^{2}$ and NIDHI SETHI* \\ 1'Department of Chemistry, Lovely Professional University, Phagwara, Punjab - 144411, India. \\ ${ }^{2}$ Department of Biotechnology, Lovely Professional University, Phagwara, Punjab - 144411, India. \\ *Corresponding author E-mail: nidhisethi_cdri@yahoo.co.in \\ http://dx.doi.org/10.13005/ojc/310149 \\ (Received: December 09, 2014; Accepted: January 11, 2015)

\begin{abstract}
Peptides are the chemical compounds which consist of amino acids coupled together by peptide linkage. Peptide derivatives are synthesized by coupling the carboxyl group of one amino acid with amino group of other. Due to the possibilities of fortuitous and unintentional reactions, various protecting groups are used to protect the carboxylic acid as well as amino groups of both the amino acids. These peptide derivatives are associated with a variety of pharmacological activities including antibacterial and antifungal activities. While doing our analysis some of the dipeptides were synthesized in a reasonable yield and purity which were fully characterised by FTIR and $\mathrm{H}^{1}$ NMR. The antimicrobial activity of these derivatives was studied and these were found to be active against two strains of fungi (Aspergillus fumigatus \& Pencillium chrysogenum) and two strains of bacteria (E. coli and Salmonella typhimurium). This provides for a future insight to work on the synthesis of these dipeptide derivatives to achieve their stability.
\end{abstract}

Key words: Dipeptides, Deprotected Analogs, Amino acid.

\section{INTRODUCTION}

Peptides are the constituents of proteins. They are biologically active chemical compounds formed by amino acid units linked together by amide linkage. They are useful pharmaceutical agents which are used for the treatment of arthritis, diabetes, cardiovascular diseases, immune diseases, growth problems and many more. Peptides are smaller in size, less immunogenic, highly active and more stable at room temperature than proteins and antibodies. Also they have low manufacturing cost.
Peptides are widely used as pharmaceutical agents due to the diversity of their constituents and their minimal toxicity. The 20 naturally occurring amino acids found in proteins offer a tremendous number of possible combinations for a peptide sequence ${ }^{1}$. Structural modifications of synthetic peptides also provide diversity in their pharmaceutical design. Cyclic peptides offers enhanced stability and retain biological activity ${ }^{2}$. We have described a simple three step procedure for the synthesis of dipeptides from component amino acids and checked their antimicrobial activity. 


\section{MATERIALS AND METHOD}

\section{Materials}

BOC- protected amino acid and Thionyl Chloride used for synthesis of dipeptides were obtained from Qualikems fine chemicals private limited (New Delhi). Amino acids like L-Tyrosine, LLeucine, L-Proline, and solvents like Dichloromethane (DCM), Methanol, Diethylether, Tetrahydrofuran (THF) and other reagents like $\mathrm{N}$ Methylmorpholine (NMM), Dimethylformamide (DMF), Trifluoroacetic acid (TFA) were purchased from Loba Chemie Pvt Ltd (Mumbai). Coupling reagent Isobutylchloroformate (IBCF) was obtained from Spectrochem Pvt Ltd (Mumbai) and Luria Bertani (LB) agar was taken from Himedia Laboratories Pvt Ltd (Mumbai). The fungal species like Aspergillus fumigatus (NCIM-902),Pencillium chrysogenum (NCIM-738) and bacterial species; E.Coli (NCIM- 2563) and Salmonella typhimurium (NCIM- 2501) used in the process are the products of NCIM, National Chemical Laboratory (Pune).

\section{Method}

Protection of carboxyl group of L-amino acids using Methanol and Thionyl chloride ${ }^{3}$

$50 \mathrm{ml}$ Methanol was taken in $250 \mathrm{~mL}$ round bottom flask under the ice cold conditions followed by the addition of 24 mmole of Thionyl chloride in a drop wise manner along with continuous stirring. After that $12 \mathrm{mmole}$ of L-amino acid (Tyrosine, Leucine and Proline)was added pinch wise. The contents of the flask were then refluxed for 4 hours. The progress of reaction was monitored time and again by TLC on readymade silica plates (Merck, UV active $\lambda_{\max } 254_{\mathrm{nm}}$ ) and the solvent was evaporated under reduced pressure. The residue was obtained as hydrochloride salt and was dried in vacuum desiccator using $\mathrm{P}_{2} \mathrm{O}_{5}$.

Coupling of methyl ester protected L-amino acid with BOC-protected L-amino acids $\mathbf{s}^{4,5}$

$7.5 \mathrm{mmole}$ of BOC-Phenylalanine was dissolved in $20 \mathrm{~mL}$ of Tetrahydrofuranin a round bottom flask followed by the addition of $7.6 \mathrm{mmole}$ of $\mathrm{N}$-Methylmorpholine. At the same time, $9 \mathrm{mmole}$ of methyl ester of amino acid (L- Leucine, L-Proline and L-Tyrosine) was dissolved in minimum amount of Dimethylformamide in another round bottom flask and 9.2 mmole of $\mathrm{N}$ - Methylmorpholine was also added to it so as to neutralise the salt under ice cold conditions. Coupling reagent Isobutylchloroformate was then added at $-15^{\circ} \mathrm{C}$ to first flask with vigorous stirring and contents of second flask were added to that. The reaction mixture was allowed to stir for 2 hours. The filtrate was evaporated under reduced pressure and the oily residue left was dissolved in ethyl acetate. It was then washed with $10 \%$ aqueous sodium bicarbonate, citric acid solution and finally with brine. The organic layer was dried over anhydrous sodium sulphate and evaporated under reduced pressure. Residue was then dried in vacuum desiccator using $\mathrm{P}_{2} \mathrm{O}_{5}$. The crude product was purified over silica gel column using Methanol : Chloroform as solvent system to get pure compound.

\section{Deprotection of protected dipeptides ${ }^{6,7}$ \\ BOC-Protected dipeptides were dissolved} in Dichloromethane in a round bottom flask having a guard tube attached to it. About $1 \mathrm{~mL}$ of Trifluoroacetic acid was added in the flask. The contents of the flask were allowed to stand for 1 hour. Solvent was then evaporated under reduced pressure and the oily residue obtained was triturated in diethylether to get solid residue which was then stored in desiccator.

\section{Antimicrobial activity}

The antimicrobial activity of protected and deprotected dipeptides was checked in vitro by Kirby-Bauer disc diffusion method ${ }^{8}$. In this method the antimicrobial activity of test compounds was examined by measuring the diameter of zone of inhibition ${ }^{9}$. The antimicrobial activity was checked against two fungal strains Aspergillus fumigatus (NCIM-902), Pencillium chrysogenum(NCIM-738) and two Gram-negative E. coli (NCIM-2563), Salmonella typhimurium(NCIM-2501) bacterial strains. LB plates were streaked by spread plate method and discs of $1 \mathrm{~mm}$ Whatsmann filter paper were soaked in 250 ppm, 500 ppm, and 1000 ppm of dipeptides (both protected and deprotected), along with Ciprofloxacin $(1 \mu \mathrm{g} / \mathrm{disc})$ as a standard and solvent solution as control and placed in the centre of the inoculated petriplates. The plates were incubated at $37^{\circ} \mathrm{C}$ and results were interpreted after $24 \mathrm{hrs}^{10}$. The results of antimicrobial activity of protected and deprotected dipeptides are shown in table1 and 2 . 


\section{RESULTS AND DISCUSSION}

\section{${ }^{1} \mathrm{H} \mathrm{NMR} ; 400 \mathrm{MHz} \mathrm{CDCl}_{3}$ (8ppm)}

1. BOC-PheLeu-OMe:0.874-0.915 (m,9H, $\left.\mathrm{CH}_{2} \mathrm{CH}\left(\mathrm{CH}_{3}\right)_{2}\right), 1.33\left(\mathrm{~s}, 9 \mathrm{H},\left(\mathrm{CH}_{3}\right)_{3} \mathrm{CO}\right), 1.49-$ $1.57\left(\mathrm{~m}, 2 \mathrm{H}, \mathrm{NHCH}_{2} \mathrm{CH}_{2} \mathrm{CH}\left(\mathrm{CH}_{3}\right)_{3}\right), 2.77-$ $2.83\left(\mathrm{~m}, 1 \mathrm{H}, \mathrm{HNCHCH}_{2} \mathrm{C}_{6} \mathrm{H}_{5}\right)$

$3.64\left(\mathrm{~s}, 3 \mathrm{H}, \mathrm{OCH}_{3}\right)$, 4.26-4.30 $\left(\mathrm{m}, 2 \mathrm{H}, \mathrm{CH}_{2} \mathrm{C}_{6} \mathrm{H}_{5}\right), 7.18-7.23\left(\mathrm{~m}, 5 \mathrm{H}, \mathrm{C}_{6} \mathrm{H}_{5}\right)$ FTIR-8400S; $v(\mathrm{C}=0)$ peak $1688 \mathrm{~cm}^{-1}, v(\mathrm{~N}$ H) peak $3065 \mathrm{~cm}^{-1}$

2. BOC-PheTyr-OMe:1.33-1.39 (m, $9 \mathrm{H},\left(\mathrm{CH}_{3}\right)_{3}$ CO), 2.54-2.66 (m, $\left.2 \mathrm{H}, \mathrm{CH}_{2} \mathrm{C}_{6} \mathrm{H}_{5}\right), 2.76-2.92$ $\left(\mathrm{m}, 2 \mathrm{H}, \mathrm{CH}_{2} \mathrm{C}_{6} \mathrm{H}_{4} \mathrm{OH}\right), 3.63\left(\mathrm{~s}, 3 \mathrm{H}, \mathrm{OCH}_{3}\right)$, 4.26-4.28 $\left(\mathrm{m}, 1 \mathrm{H}, \mathrm{NHCHCH}_{2} \mathrm{C}_{6} \mathrm{H}_{5}\right), 4.57$ $4.59\left(\mathrm{~m}, 1 \mathrm{H}, \mathrm{NHCHCH} \mathrm{C}_{6} \mathrm{H}_{4} \mathrm{OH}\right), 6.68-6.70$ $\left(\mathrm{m}, 5 \mathrm{H}, \mathrm{C}_{6} \mathrm{H}_{5}\right), 7.16-7.29\left(\mathrm{~m}, 4 \mathrm{H}, \mathrm{C}_{6} \mathrm{H}_{4} \mathrm{OH}\right)$ FTIR-8400S; $v(\mathrm{C}=\mathrm{O})$ peak $1688 \mathrm{~cm}^{-1}, v(\mathrm{~N}-\mathrm{H})$ peak $3063 \mathrm{~cm}^{-1}$

3. $\mathrm{BOC}-\mathrm{PhePro}-\mathrm{OMe}: 1.27-1.47$ $\left(\mathrm{m}, 9 \mathrm{H},\left(\mathrm{CH}_{3}\right)_{3} \mathrm{CO}\right), 1.89-2.18\left(\mathrm{~m}, 2 \mathrm{H}, \mathrm{CH}_{2} \mathrm{C}_{6} \mathrm{H}_{5}\right.$ ), 2.93-3.46 (m,4H, $\left.\mathrm{NCH}\left(\mathrm{CH}_{2}\right)_{2}\right), 3.57-3.63$ (m, $\left.1 \mathrm{H}, \mathrm{NCH}\left(\mathrm{CH}_{2}\right)_{3}\right), \quad 3.70\left(\mathrm{~s}, 3 \mathrm{H}, \mathrm{OCH}_{3}\right)$, 4.67-5.03 (m,1 $\left.1 \mathrm{H}, \mathrm{NHCOCHCH} \mathrm{C}_{6} \mathrm{H}_{5}\right), 7.20-$ $7.28\left(\mathrm{~m}, 5 \mathrm{H}, \mathrm{C}_{6} \mathrm{H}_{5}\right)$ FTIR-8400S; $v(\mathrm{C}=\mathrm{O})$ peak $1642 \mathrm{~cm}^{-1}, v(\mathrm{~N}-\mathrm{H})$ peak $3431 \mathrm{~cm}^{-1}$

4. PheLeu OMe: $v(\mathrm{C}=\mathrm{O})$ peak $1672 \mathrm{~cm}^{-1}, v(\mathrm{~N}$ H) peak $3289 \mathrm{~cm}^{-1}$

5. PheTyr-OMe: $v(\mathrm{C}=\mathrm{O})$ peak $1671 \mathrm{~cm}^{-1}, v(\mathrm{~N}-$ H) peak $3178 \mathrm{~cm}^{-1}$

6. PhePro-OMe: $v(\mathrm{C}=\mathrm{O})$ peak $1699 \mathrm{~cm}^{-1}, v(\mathrm{~N}$ H) peak $3144 \mathrm{~cm}^{-1}$

The antimicrobial activity of protected and deprotected dipeptides against fungal and bacterial strains is shown in table 1 and 2. Among protected dipeptides BOC-PhePro-OMe shows maximum potency against fungi Aspergillus fumigatus with inhibition zone diameter of $11 \mathrm{~mm}$ at $1000 \mathrm{ppm}$ (standard 20mm). This compound is not so effective against Pencillium chrysogenum. But it shows good antibacterial activity against gram- negative strains of E.coli $(8 \mathrm{~mm})$ and Salmonella typhimurium (10 $\mathrm{mm}$ ). This compound shows moderate potency

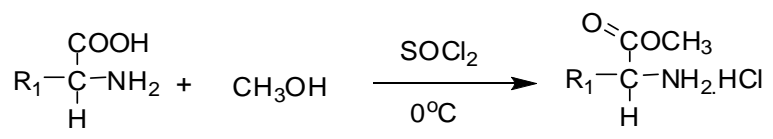

Step 1: Carboxyl group protection of L-amino acids with methyl ester:

(Where amino acids taken are Tyrosine, Leucine, and Proline)

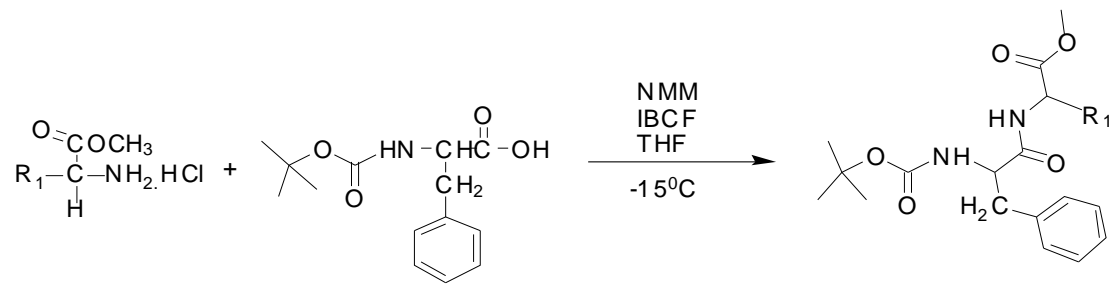

Step 2: Coupling of protected amino acids to form protected dipeptide

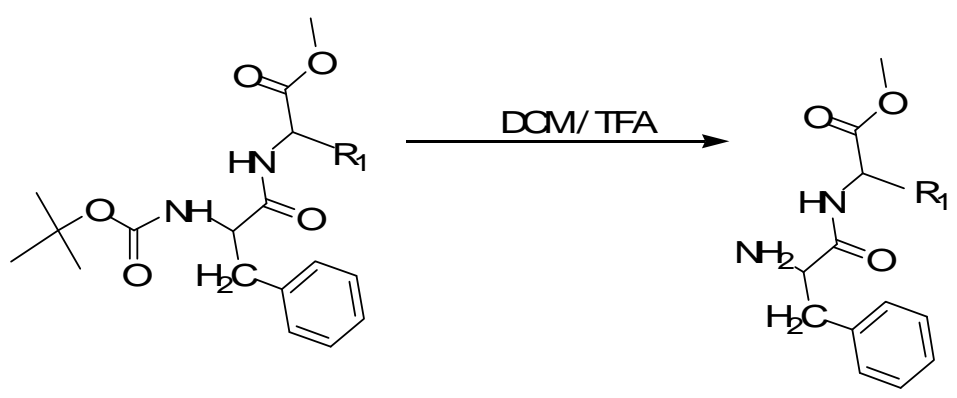

Step 3: Deprotection of protected dipeptides 


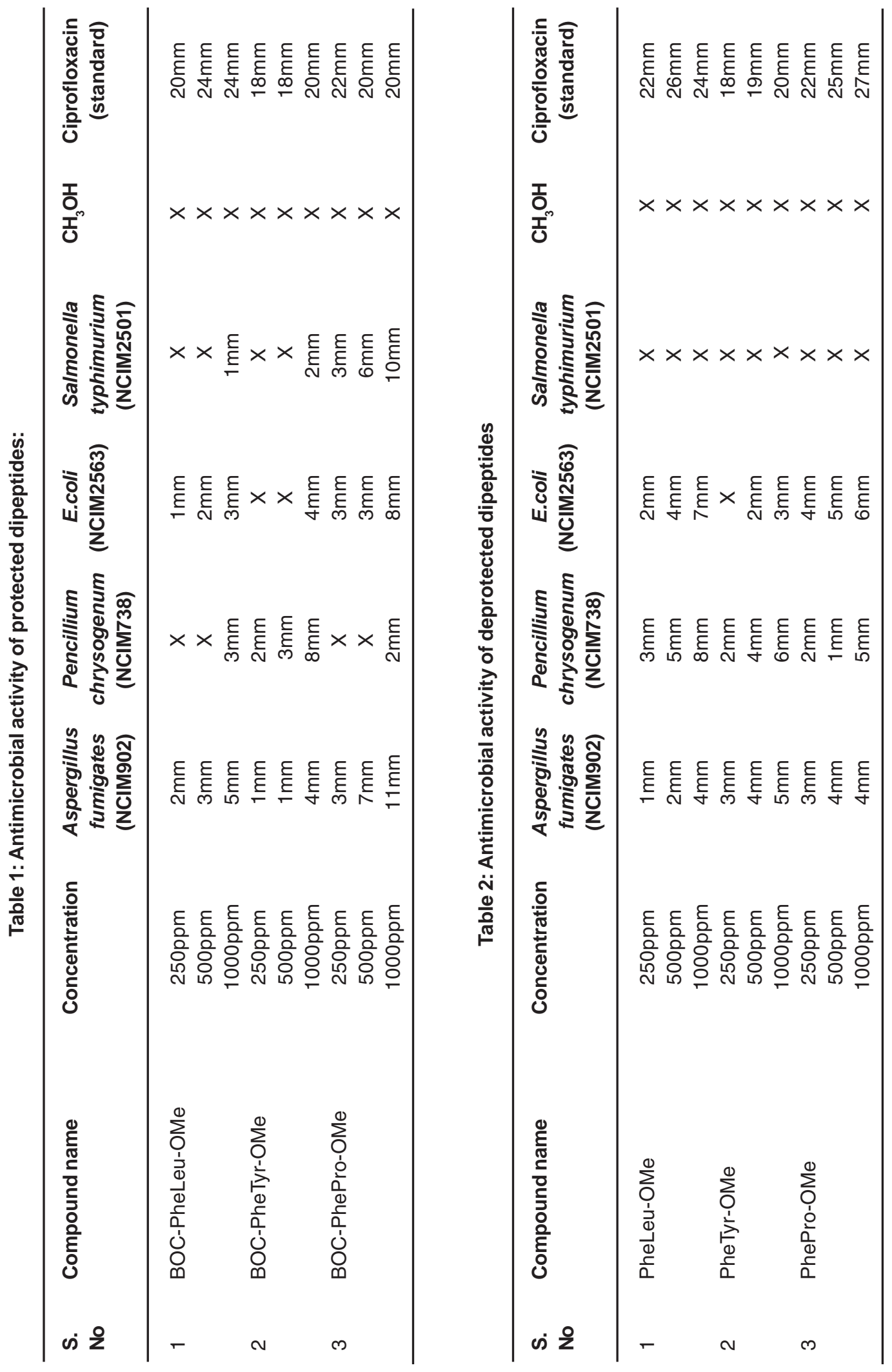


against Aspergillus fumigatus, E.coli and Salmonella typhimurium at 250 and 500ppm concentrations.

BOC-PheLeu-OMe is negligibly effective against Aspergillus fumigatus at all concentrations (250, 500 and 1000 ppm) with zonal diameter of $1 \mathrm{~mm}, 2 \mathrm{~mm}$ and $4 \mathrm{~mm}$ respectively while standard has diameter of $20 \mathrm{~mm}-24 \mathrm{~mm}$.

Protected dipeptide BOC-PheTyr-OMe show moderate activity against fungal strain Pencillium chrysogenum at $1000 p p m$ ( $8 \mathrm{~mm})$.It is not effective against Aspergillus fumigatus, E.coli and Salmonella typhimurium at concentrations of 250, 500 and 1000ppm.

Deprotected dipeptides also show antibacterial and antifungal activities against the four strains. All the three deprotected dipeptides Pheleu-OMe, PheTyr-OMe, PhePro-OMe show moderate antifungal activity against Aspergillus fumigatus at concentrations of 250ppm,500ppm and 1000 ppm. They are not showing any activity against Salmonella typhimurium even at higher concentration of 1000ppm.Deprotected dipeptides PheLeu-OMe, PheTyr-OMe, PhePro-OMe are showing good antifungal activity against fungal strain Pencillium chrysogenum at higher concentration (1000ppm) with zonal diameter of $8 \mathrm{~mm}, 6 \mathrm{~mm}$ and $5 \mathrm{~mm}$ (standard $22-27 \mathrm{~mm}$ ). They are also effective against gram-negative bacteria E.coliat 1000ppm with inhibition zone diameter of $7 \mathrm{~mm}, 3 \mathrm{~mm}$ and $6 \mathrm{~mm}$ respectively.

\section{CONCLUSION}

With the increase in pollution all over the world, various infectious diseases are emerging; also the microorganisms are becoming resistant to existing antibiotics. Therefore it is becoming a challenge for researchers to develop new methods for the treatment of these diseases and microorganisms ${ }^{11}$.From the results, we found that these protected and deprotected dipeptides exhibit antimicrobial activities at different concentrations. Out of these compounds BOC-PhePro-OMe and PheLeu-OMe(fig 1) are showing good antimicrobial activity against biologically important pathogens so these can be used as potent therapeutic agents after their further investigations.

\section{ACKNOWLEDGMENTS}

We are grateful to Dr. Joginder Singh for antimicrobial activity, Lovely Professional University for lab facility and SAIF, Panjab University Chandigarh for NMR facility.

\section{REFERENCES}

1. Bryan, A.; Joseph, L.;Bennett,J.A.;Jacobson, H.I.; Andersen, T.T.Peptides 2011, 32,25042510

2. Gentilucci, L.; Cardillo, G.; Tolomelli, A.; Squassabia, F.; Chiriano, D.M.G. Comb Chem High Throughput Screen 2009,12, 929-939

3. Young,P.E.; Campbell, A. Journal of chemical education 1982, 59, 701-702

4. Anderson, G.W.; Zimmerman, J.E.; Callahan, F.M.J. Am. Chem. Soc. 1967,89, 5012-5017

5. Joullie, M.M.; Lassen, K.M. Arkivoc 2010, 8, 189-250

6. Hameurlaine, A.; Saved, W.A.; Rahman, A.H.A. Monatsh Chem.2008, 139, 15071511
7. Zinelaabidine, C.; Souad, O.; Berredjem, J.Z.; Eddine, A.N.International journal of Chemistry 2012,4, 73-79

8. Bauer, A.W.; Kirby, W.M.M.; Sherris, J.C.; Turck, M.Am.J.Clin.Pathol. 1996,45, 493-496

9. Hossain, S.M.; Easmin, S.; Islam, S.M.; Mamunur, R.J.Pharm.Pharmacol. 2004,56, 1519-1520

10. Nagarajan,K.; Senthamarai, R.; Devi, K.; Deepashalini, S.; Anandh, N.; Krishnaveni,P.; Mazumder, A.; Ghosh, L.K.; Umadevi, G. Journalof cell and tissue research 2008,8,1265-1269

11. Strohl W. R., Biotechnology of Antibiotics, Vol. 82.;Marcel Dekker. New York, (1997) 